Sympozjum

Rok XXIII 2019, nr 2(37), s. 197-213

\author{
ks. Adam Pastorczyk SCJ \\ Uniwersytet Papieski Jana Pawła II w Krakowie \\ ORCID: 0000-0002-0810-3878; e-mail: scj.adam@gmail.com \\ https://doi.org/10.4467/25443283SYM.19.030.11432
}

\title{
MARYJA JAKO IKONA SAKRAMENTALNEGO STYLU ŻYCIA W DUCHU ŚWIĘTYM
}

\section{MARY AS AN ICON OF A SACRAMENTAL LIFESTYLE IN THE HOLY SPIRIT}

\begin{abstract}
Abstrakt
Celem niniejszego artykułu jest ukazanie Maryi jako ikony sakramentalnego stylu życia w Duchu Świętym. Ikoniczność życia Maryi polega przede wszystkim na manifestacji nie swojego, lecz otrzymanego w dniu Zwiastowania, nowego życia - Jezusa Chrystusa. Maryja nie naucza doktryny, nie opisuje Boga, nie tworzy o Nim abstrakcyjnych pojęć, lecz pozwala doświadczyć Jego realnej obecności. Od samego początku, również wspólnota Kościoła uczestniczy w ikonicznym stylu życia Maryi, ukazując światu przyjętą nowość. Tego sakramentalnego stylu życia chrześcijanie ani nie pożyczyli, ani nie skopiowali od nikogo. To jest coś na wskroś oryginalnego, coś, czego świat im nie może dać, ale za to oni mogą dać to światu.

Słowa kluczowe: Maryja, ikona, życie organiczne, życie sakramentalne, Duch Święty
\end{abstract}




\section{Abstract}

The purpose of this article is to show Mary as an icon of the sacramental lifestyle in the Holy Spirit. The iconic character of Mary's life consists above all in the manifestation, not her own, but received on the day of the Annunciation, the new life - Jesus Christ. Mary does not teach the doctrine, does not describe God, does not create abstract concepts about Him, but allows us to experience His real presence. From the very beginning, the Church also participates in the iconic style of Mary's life, showing the accepted novelty to the world. Christians have neither borrowed nor copied this sacramental lifestyle from anyone. This is something completely original, something that the world cannot give them, but they can give it to the world.

Keywords: Mary, icon, organic life, sacramental life, the Holy Spirit

\section{Wstęp}

Od pierwszej niedzieli Adwentu Anno Domini 2018 hasłem roku duszpasterskiego Kościoła w Polsce jest sentencja: „W mocy Bożego Ducha”. Przy okazji kończącego się niebawem roku liturgicznego i pielgrzymki Polskiej Prowincji Księży Sercanów do sanktuarium Matki Bożej Błogosławionego Macierzyństwa w Krakowie-Płaszowie (12 października 2019 roku), warto zastanowić się nad tym, czy ta myśl i wypływające z niej działania duszpasterskie, wniosły realną, duchową wartość w życie Polaków i Polek, w życie sercańskich wspólnot, czy może pozostały tylko pustym projektem i zgrabnie ujętą ideą.

Odpowiedzi na to pytanie trudno znaleźć w kościelnych statystykach dotyczących ilości przeprowadzonych akcji duszpasterskich, wydarzeń modlitewnych czy wyjazdów pielgrzymkowych, bowiem, niestety zdarza się, że choć ich uczestnicy, doznając duchowych uniesień, krzyczą, skaczą i płaczą, to jeszcze tego samego dnia, od wieczora aż do rana, albo piją do nieprzytomności, albo oglądają najgorsze sprośności, które oferuje im światłowodowy internet, albo też następnego dnia wychodzą na ulicę swojego miasta, plując, wyzywając i rzucając kamieniami w inaczej 
myślących od nich ludzi. Jeśli tak jest, oznacza to, że ludzka mentalność nie została jeszcze napełniona Duchem Świętym i ktoś inny nią kieruje ${ }^{1}$.

Odpowiedź na pytanie o autentyczne życie „w mocy Bożego Ducha”, a więc pytanie o stokrotny, sześćdziesięciokrotny i trzydziestokrotny plon, ukryta jest raczej w nieudawanej, czasami szarej, ale za to prawdziwej, ludzkiej codzienności. Odpowiedzi dostarczyć powinno także osobiste i wspólnotowe spotkanie $\mathrm{z}$ wpisaną od dziesięcioleci w sercańską tożsamość ikoną Matki Bożej Błogosławionego Macierzyństwa. Właśnie w tym obrazie Maryi, będącej Arcydziełem Boskiego Ikonografa, stanowiącej ikonę nowego stylu życia w Duchu Świętym, można zobaczyć, czy ludzkie życie jest spójne, czy jest pełne, jak pełne jest ziarno w kłosie, czy też jest niespójne, składające się z wielu, bardzo słabo powiązanych ze sobą fragmentów, nietworzących realnej i logicznej całości, lecz raczej stanowiących karykaturę człowieczeństwa: człowieczeństwa dnia i nocy, człowieczeństwa realizmu i udawania, człowieczeństwa prawdy i kłamstwa.

\section{Sekwencja epok}

Nietrudno zauważyć, że powyższe fragmenty ludzkiego życia nie tylko do siebie nie pasują, lecz także się wzajemnie wykluczają. Podobne doświadczenie może przeżywać miłośnik literatury lub koneser sztuki pochodzącej z różnych epok (średniowiecza, renesansu, baroku, oświecenia, romantyzmu, pozytywizmu itd.). Ktoś taki z łatwością dostrzeże, że bezpośrednio sąsiadujące ze sobą epoki, bardzo się od siebie różnią. Chciałoby się powiedzieć, że nawet się od siebie oddalają, przeciwstawiają się sobie, nie chcą mieć ze sobą nic wspólnego.

Zgoła inaczej jest $\mathrm{w}$ przypadku epok, które bezpośrednio nie następowały po sobie. W tym przypadku można dostrzec pewne podobieństwa, wspólne inspiracje. Zgodnie z tym kluczem, średniowiecznej myśli nie należy szukać w następującej po niej epoce renesansu (ta, jak już wspomniałem, nie chce mieć ze średniowieczem nic wspólnego), lecz

1 Por. N. Govekar (red.), Il rosso della piazza d'oro. Intervista a Marko Ivan Rupnik su arte, fede ed evangelizzazione, Roma 2013, s. 129. 
dopiero w baroku, a myśli barokowej, nie w sąsiadującym z nią oświeceniu, lecz dopiero w romantyzmie.

To pobieżne spojrzenie na historię ludzkiej kultury pozwala wyodrębnić dwie tendencje, dwie główne epoki: organiczną, w której pielęgnowane jest życie oraz racjonalistyczną (techniczną), w której dominuje rozum. W pierwszym przypadku, życie zostaje wyrażone za pomocą poezji, liturgii, sztuki ${ }^{2}$. Natomiast $\mathrm{w}$ drugim, prymat rozumu wyrażony jest za pomocą idei, doktryny, metody, systemu³.

Romano Guardini, jeden z najwybitniejszych teologów liturgii, tuż po zakończeniu pierwszej wojny światowej stwierdził, że po kilku wiekach panowania epoki racjonalizmu, człowiek ponownie wszedł w epokę poświęconą życiu, epokę organiczną ${ }^{4}$. Czym ona jest i jakie niesie ze sobą konsekwencje dla współczesnego człowieka, skoro właśnie w tej epoce przyszło mu żyć i ewangelizować?

\section{Maryja w epoce życia}

Biblijna, jak i powszechna historia człowieka, wskazuje wyraźnie, że Bóg przygotowuje ludzkość do jednego wydarzenia. Na różne sposoby trudzi się, by człowiek Go przyjął, by stał się Jego matką. Mimo podjętych w tym kierunku działań, człowiek, co pokazuje Betlejem i Golgota, nie umiał, nie potrafił, nie chciał przyjąć Boga. Tą, która Go przyjęła, była Maryja. Począwszy od dnia Zwiastowania, Maryja całą sobą mówi o przyjętej nowości, o tym, że Bóg Jej nie oszukał, że zrealizował w Niej to, co uprzednio wobec Niej zamierzył, tzn. że powołał Ją do czegoś wielkiego, do czegoś, co do tej pory mogła odczuwać tylko intuicyjnie, a teraz zostało Jej to objawione ${ }^{5}$.

2 Por. tamże, s. 122-123.

${ }^{3}$ Por. tamże, s. 53-54.

4 Por. R. Guardini, La fine dell'epoca moderna, Brescia 1960², s. 60; G. Bonaccorso, Il rito e l'altro. La liturgia come tempo, linguaggio e azione, Città del Vaticano 2001, s. 23.

5 Por. C. Pellegrino, Maria di Nazaret, Profezia del Regno. Un approccio narrativo a Lc 1,34, Roma 2014, s. 99-100. 
Pierwszą biblijną postacią, która zobaczyła w Maryi nowy styl życia w Duchu Świętym, była Elżbieta, dla której widok Maryi znaczył więcej niż tysiąc słów. W tym jednym momencie, w swej krewnej nie widziała już Miriam z Nazaretu, lecz Matkę swojego Pana (por. Łk 1,43). Wystarczyło Jej jedno spojrzenie, aby w twarzy Maryi, zobaczyła inną twarz, twarz samego Jezusa..., aby poczuła, że Maryja przyniosła jej niedostrzegalną gołym okiem prawdziwą obecność .

Gdy Elżbieta spotyka Maryję, nie zachowuje się jak typowa kobieta. Nie pyta: Jak? Kiedy? Gdzie? Dlaczego? Nie żąda od Niej żadnych wyjaśnień. Od razu umie przeczytać stojącą przed nią ikonę Maryi ${ }^{7}$. W spotkaniu z Maryją Elżbieta zachowuje się jak nietypowy czytelnik Drogi na Górę Karmel św. Jana od Krzyża. Bierze do ręki książkę, ale jej nie czyta. Wystarczy jej jedno spojrzenie na umieszczony na początku książki rysunek drogi wiodącej na tytułową „Górę Karmel”, aby zrozumiała całą jego treść. To spojrzenie jest jednoczesnym czytaniem i rozumieniem. Kto zatem, patrząc na ten szkic, rozumie, czym jest Droga na Górę Kar$m e l$, ten w kilka chwil oszczędza sobie kilkutygodniowego czytania całego dzieła, w którym Jan od Krzyża nie robi nic innego, jak tylko wyjaśnia swój rysunek. Właśnie w taki sposób Elżbieta przeczytała ikonę Maryi ${ }^{8}$.

Dramat współczesnego świadka Chrystusa polega jednak często na tym, że używa on setek słów, porównań, definicji czy opowiadań, a na końcu ludzie i tak go pytają: a czy ten ktoś, o kim mówiłeś: niepojęty, niezmierzony, wszechmogący, nieskończony, miłosierny..., czy on naprawdę istnieje? O ile wcześniej nie połamią sobie zębów na teologicznych terminach, powiedzą mniej więcej tak: widzę, że w obszarze trynitologii, chrystologii, pneumatologii, czujesz się jak ryba w wodzie, ale gdzie tego wszystkiego mogę doświadczyć, gdzie to mogę zobaczyć?

${ }^{6}$ Por. tamże, s. 175-176; G. Bonaccorso, La comunicazione non verbale in un'ecclesiologia dell'incontro, „Annali Studi Religiosi” 1 (2000), s. 59; TEnżE, Il rito e l'altro, dz. cyt., s. 231-232.

7 Por. N. Govekar (red.), Il rosso della piazza d’oro, dz. cyt., s. 143.

8 Symbol nie potrzebuje tłumaczenia, gdyż sam jest w stanie siebie wyjaśnić. Życie symboliczne (maryjne), o którym tutaj mówimy, odkrywa, objawia oraz przekazuje rzeczywistość, którą wyraża. Por. tamże, s. 11. 23. 
Dlaczego wierzący i niewierzący tak bardzo potrzebują odpowiedzi na te fundamentalne pytania? Bo mają świadomość, że kiedy rodzą się do życia, w tym samym momencie w powietrzu unosi się już zapach ich własnego pogrzebu. Jaki jest sens życia, skoro wiem, że i tak muszę umrzeć? Wszyscy mamy świadomość, że nasze życie biegnie w kierunku śmierci i robimy wszystko, by znaleźć stały ląd, nowy świat, w którym czeka na nas życie. Próby odpowiedzi na ten ludzki dramat podejmują wszystkie religie świata. Wszystkie one jako remedium stosują coś w rodzaju odwrotności: jeśli do tej pory ludzkie życie biegło od narodzin do śmierci, tak teraz biegnie ono od śmierci do życia ${ }^{9}$. Wystarczy przyjrzeć się głębiej tajemnicy naszej wiary i sakramentowi chrztu świętego, aby dokładnie zrozumieć o czym mówimy: nowe życie otrzymane na chrzcie świętym jest śmiercią w Chrystusie i równoczesnym zmartwychwstaniem z Nim do niekończącego się już życia. Przed chrztem nasze życie biegło od narodzin do śmierci. Po chrzcie, biegnie od śmierci do życia.

Śmierć jest końcem działania, niemożliwością poruszania się. Śmierć dotyka także emocji, jest lękiem przed śmiercią. Gdy Maryja spotyka posuniętą już w latach Elżbietę, jej obecność dotyka właśnie tych dwóch wymiarów śmierci: niemożliwości poruszania się oraz lęku. Po pozdrowieniu Maryi, Elżbieta czuje w sobie poruszające się życie, czuje nową siłę, moc która dotyka całego jej ciała. Ma świadomość, że jej życie nie jest ukierunkowane na śmierć, lecz na życie. Zaraz potem, bez lęku, bez obaw, wydaje okrzyk pełen nadziei: „Błogosławionaś Ty między niewiastami i błogosławiony jest owoc Twojego łona" (Łk 1,42b). Zatem sacrum, które Maryja przynosi Elżbiecie, nie jest przeciwne profanum, lecz jest odpowiedzią pełną nadziei, nadaniem sensu profanum i ukazaniem jego właściwego kierunku ${ }^{10}$.

Maryja jest ikoną nowego, innego świata. Nie świata wymyślonego, teoretycznego, pojęciowego, lecz realnego. W Maryi każdy może przejść inicjację chrześcijańską, która nie jest poznawaniem doktryny. Czym zatem jest ta inicjacja? Jest uczeniem się bycia wewnątrz, bycia zanurzo-

\footnotetext{
9 Por. G. Bonaccorso, Il rito e l'altro, dz. cyt., s. 325-326.

10 Por. tamże, s. 68-69. 325.
} 
nym, bycia w kimś. Jeżeli człowiek będzie wewnątrz, nie obok, nie naprzeciw, lecz wewnątrz chrześcijańskiej wiary, jeżeli zatem pozwoli, aby wylana na jego głowę woda chrztu świętego spłynęła po całym jego ciele, zanurzając go w tajemnicy Chrystusa, zdobywając dla niego pogańskie ziemie swojego życia, to wtedy, w sakramencie Eucharystii, Chrystus zanurzy się prawdziwie w nim.

Przygotowując dzieci do Pierwszej Komunii Świętej i ucząc je Małego katechizmu, katecheta ma nadzieję, że zdobyta wiedza będzie w pewnym sensie wyznacznikiem ich wiary. Jednakże Maryja nie przyniosła Elżbiecie żadnego katechizmu, lecz zanurzyła ją w obecności Boga. Owszem, jako pewien rodzaj katechizmu, można byłoby tu potraktować wyśpiewaną w dalszej kolejności pieśń Magnificat, w której Maryja opisuje Boga, ale szczerze mówiąc, ta pieśń byłaby zupełnie niezrozumiała, gdyby Elżbieta nie została wcześniej zanurzona w realnej obecności Chrystusa ${ }^{11}$.

W jaki sposób dziecko, oczywiście jeszcze przedintelektualnie, może poznać swoich rodziców? Oczywiście poprzez ich realną obecność w jego życiu. Dziecko nawet jeżeli w pierwszych dniach życia nie jest w stanie intelektualnie poznać swoich najbliższych, ma już pewne doświadczenie ich obecności, ich troski, czułości. Poznaje ich poprzez obecność. Wraz z rozwojem dziecka, dochodzi oczywiście poznanie intelektualne, ale jeśli nie będzie tego pierwotnego doświadczenia, jeśli realnie nie spotka mamy i taty, to opisywanie ich wydaje się być pozbawione sensu ${ }^{12}$.

Podobnie jest w przypadku Boga. Mogę oczywiście mówić o Jego miłości, dobroci i miłosierdziu, ale jeśli Go nie spotkam, to te definicje, za pomocą których będę Go opisywał, pozostaną zawieszone w próżni. Z tyłu głowy zawsze będzie odzywać się to samo pytanie: a czy ten ktoś, rzeczywiście istnieje?

11 R. Guardini zauważa, że ludzkie poznanie jest wpierw aktem całego człowieka, a dopiero potem staje się elaboracją jego intelektu. Por. R. GUARDINI, La funzione della sensibilità nella coscienza religiosa, w: G. Sommavilla (red.), Scritti filosofici, t. 2, Milano 1964, s. 154; G. BonacCorso, Il rito e l'altro, dz. cyt., s. 32.

12 Por. E. Salmann, L'evento intercorporeo tra verità e rito, w: A. N. Terrin (red.), Liturgia e incarnazione, Padova 1997, s. 30-31. 35-37; N. GovekAR (red.), Il rosso della piazza d'oro, dz. cyt., s. 124. 


\section{Kościół w epoce życia}

Od samego początku, chrześcijanie ukazywali światu otrzymaną nowość, nowy styl życia, którym żyła Maryja w Duchu Świętym. Jego podstawę stanowi oczywiście styl życia samego Boga, Trójcy Świętej. Styl tego życia Jezus wyraził słowami: „Kto mnie widzi, widzi także i Ojca” (J 14,9). Chodzi o życie sakramentalne, o odkrywanie w jednej rzeczywistości, innej rzeczywistości, o patrzenie na osobę i zobaczenie w niej innej osoby ${ }^{13}$. To myślenie, a co za tym idzie, takie patrzenie, jest typowo chrześcijańskie.

Dla chrześcijan nie powinno być to żadnym zaskoczeniem, bo ilekroć uczestniczą w Eucharystii, patrząc na położony na patenie chleb, odkrywają w nim Ciało Syna Bożego. Gdy piją konsekrowane wino, przyjmują je jako Jego życie ${ }^{14}$. Gdy słuchają słowa Bożego, staje się ono dla nich lectio divina, Bożym czytaniem - Bóg sam czyta im swoje Słowo ${ }^{15}$. Gdy wpatrują się w Maryję, w jej oczach, w jej gestach dostrzegają przede wszystkim owoc jej łona, samego Jezusa. Jeśli dobrze przypatrzą się obliczu świętego, odkryją w nim twarz innego świętego, a w niej rzeczywistość dla której on żyje - Chrystusa ${ }^{16}$.

Można powiedzieć, że prawdziwym chrześcijaninem jest ten, kto żyjąc w świecie, odkrywa, że żyje w świecie ikon i umie przeczytać to, co zostało w nich zapisane. Dla tradycji wschodniej jasnym jest, że to właśnie w nich znajduje się najważniejsza i najgłębsza prawda chrześcijańskiego życia ${ }^{17}$. Im bardziej ktoś umie odczytać ją w otaczających go ikonach, tym bardziej może zostać nazwany chrześcijaninem. Chrześcijanin pierwszego tysiąclecia nie potrzebował do tego opisu, legendy, dodatkowego

13 Por. tamże, s. 121-123.

14 Por. T. ŠPIDLÍk, M. I. RupNik, Una conoscenza integrale. La via del simbolo, Roma 2010, s. 249-250.

15 Por. K. Wons, Cała piękna. Lectio divina z Maryją, Kraków 2017, s. 56.

16 Por. N. Govekar (red.), Il rosso della piazza d’oro, dz. cyt., s. 46-47; M. Tenace, Cristiani si diventa. Dogma e vita nei primi tre concili, Roma 2013, s. 195.

17 Por. T. ŠpIdLık, La preghiera secondo la tradizione dell'Oriente cristiano, Roma 2008, s. 288-289. 
klucza, narzędzi tak bardzo potrzebnych współczesnemu człowiekowi. Tej sakramentalności uczył się od dziecięcych lat ${ }^{18}$.

Szczególnym miejscem, w którym doświadczał tego nowego stylu życia, była sprawowana liturgia. Liturgia, która jest paschą, w której dokonuje się przejście. Widać to szczególnie na ścianach starochrześcijańskich kościołów, które nie stanowią dodatku do sprawowanej liturgii, lecz są odbiciem tego, co się w niej dokonuje. To sakramentalne myślenie przetrwało aż po dziś dzień, bowiem w dniu poświęcenia kościoła, jego ściany, podobnie jak sam ołtarz, zostają namaszczone, aby były odbiciem wydarzenia, które się na nim dokonuje. Inaczej mówiąc, ściany są lustrem, zwierciadłem przejścia, paschy Chrystusa. Przyjmują na siebie i zachowują w sobie eucharystyczną tajemnicę. Są wyrazicielem życia i modlitwy Kościoła ${ }^{19}$, dlatego też, gdy ludzie wchodzą do kościoła, to nawet wtedy, gdy aktualnie nie jest sprawowana liturgia, Kościół celebruje i naucza ${ }^{20}$.

Wystarczy zobaczyć na ścianach kościoła biblijne przedstawienie wody, aby można było zrozumieć historię ludzkości i swoją osobistą: ład i harmonię, którą wprowadził Bóg, oddzielając wody pod sklepieniem od tych ponad sklepieniem (por. Rdz 1,6-8); konsekwencję ludzkiego grzechu wyrażoną przy pomocy wzburzonych fal potopu (por. Rdz 7,17-19); tęsknotę Samarytanki za prawdziwym, nieudawanym życiem, za znalezieniem prawdziwej, gaszącej jej pragnienie wody (por. J 4,15); tonącego w wodach jeziora Genezaret Piotra i ratującego go Jezusa (por. Mt 14,30-31). Wszystkie te sceny, mimo iż pochodzą z różnych biblijnych historii, nawzajem się wyjaśniają i opowiadają o sobie. Nie ma ani jednego elementu, który funkcjonowałby samodzielnie. Nie ma żadnej samotnej wyspy. Nie ma hermetycznie zamkniętych, bezokiennych monad. Przeciwnie, wszystkie nadają sens całości, a każda z osobna znajduje sens i wyjaśnienie $\mathrm{w}$ innej ${ }^{21}$.

${ }^{18}$ G. Bonaccorso odwołuje się tu do E. Drewermanna, stwierdzając, że myślenie człowieka przez wiele wieków kształtowało się nie poprzez usłyszane słowa, lecz poprzez widziane obrazy i symbole. Por. G. Bonaccorso, Il rito e l'altro, dz. cyt., s. 230.

19 Por. N. Govekar (red.), Il rosso della piazza d'oro, dz. cyt., s. 238.

20 Por. tamże, s. 65-66.

21 Por. tamże, s. 121-123. 
Podobnie rzecz się ma z Eucharystią. To nie część mówi o całości, lecz całość wyjaśnia poszczególne części. W związku z tym nie można powiedzieć, że słowa konsekracji stanowią centralną część liturgii, bo bez całego kontekstu, w którym się znajdują, nic one nie znaczą. Cała liturgia, a nie tylko jej część, jest wyrazem realnej obecności Boga.

Nauczanie Kościoła, jak łatwo można zauważyć, oparte jest na życiu chrześcijan, a życie chrześcijańskie opiera się o dogmaty. Życie chrześcijan jest liturgią, jest sakramentalne, jest nim nawet wtedy, gdy znajduje się poza budynkiem kościoła. Pierwsze wiążące cały Kościół powszechny stwierdzenia dogmatyczne zostały sformułowane dopiero w IV wieku. Nie były one jednak ludzką filozofią, lecz stanowiły potwierdzenie istniejącego już życia Kościoła, jego liturgicznego i sakramentalnego charakteru, zgodnie ze znaną nam zasadą lex orandi lex credend $i^{22}$.

Nie inaczej jest w naszej epoce. 13 października 2019 roku kościół parafialny w Krakowie-Płaszowie został oficjalnie ogłoszony sanktuarium Matki Bożej Błogosławionego Macierzyństwa. Nie wymyślił tego ani ksiądz arcybiskup, ani księża sercanie, lecz jest to owocem życia wielu małżeństw, wielu rodzin, także rodziny sercańskiej, które przed ikoną Matki Bożej Płaszowskiej wyprosiły wiele łask, $\mathrm{w}$ tym łaskę upragnionego rodzicielstwa.

Po raz kolejny należy stwierdzić: najpierw jest życie, potem dekret. Najpierw żywa wiara, potem doktryna. To jest ta nowość, którą chrześcijaństwo wnosi do świata. Nowość, którą owego dnia Miriam z Nazaretu przyniosła swej krewnej Elżbiecie, a ona natychmiast to zauważyła.

\section{Epoka krytyczna i zwycięstwo idei}

Patrząc jednak na współczesne chrześcijaństwo, wydaje się, że jego pierwotna mentalność zanikła. Co prawda, na ołtarzu dokonuje się ta sama liturgia, ale ściany kościołów coraz mniej ją wyjaśniają, a zatem już nie celebrują i nie nauczają jak dawniej ${ }^{23}$. W przestrzeni kościelnej po-

22 Por. tamże, s. 46-47; M. Tenace, Cristiani si diventa, dz. cyt., s. 12-32.

23 Dawniej, sztuka kościelna stała w centrum ludzkiego doświadczenia wiary i wchodziła w relację z człowiekiem w czasie jego najgłębszych życiowych doświadczeń. Obecnie, sztuka ta wyemigrowała do muzeów, gdzie znajduje się z dala od ludzkiego życia. Por. N. Govekar (red.), Il rosso della piazza d'oro, dz. cyt., s. 67. 
jawia się coraz więcej elementów, które funkcjonują samodzielnie, nie łączy ich żadna głębsza wizja, żadna teologia. Czasami nawet wzajemnie się wykluczają. W konsekwencji porozrzucane po całym kościele elementy bardziej służą dewocji, aniżeli budowaniu i rozwijaniu prawdziwej wiary ${ }^{24}$.

Cóż dopiero powiedzieć, gdy chrześcijanin wyjdzie poza drzwi kościoła i zakrystii..., a wyjść musi... Wtedy dopiero okazuje się, że mentalność chrześcijańska jest w wielu środowiskach całkowicie nieobecna. Co się wydarzyło? W jaki sposób świat, krok po kroku, zaproponował chrześcijanom swoją mentalność, swoją wizję życia? Dlaczego ją przyjęli? Dlaczego naśladują świat? W ten sposób świat ich zwyciężył, a przecież Chrystus powiedział: „Jam zwyciężył świat” (J 16,33).

Zaczęło się to dużo wcześniej, ale dobrze oddaje to namalowany na jesieni 1830 roku przez Eugène’a Delacroix obraz Wolność wiodąca lud na barykady. Upamiętnia on wydarzenia rewolucji lipcowej z tego samego roku. Rewolucja ta skierowana była przeciwko absolutyzmowi monarchii Karola X. Na swym obrazie Delacroix ukazał ideę wolności jako kobietę stąpającą po trupach, po ludzkich zwłokach. Projekt wolności zwycięża. Idea znaczy więcej niż osoba. Cel jest jasno określony, dlatego należy go osiągnąć za wszelką cenę, usprawiedliwiając jednocześnie podjęte środki. Jak łatwo można zauważyć, chodzi o idée fixe. Chodzi o ideę, która często przeradza się w ideologię. Wymyślona idea ma pierwszeństwo przed życiem. Najpierw doktryna, potem praktyka ${ }^{25}$.

Wiele takich idei czy projektów, także w bliższej nam historii, w bliższych nam środowiskach, doprowadziło do podobnych tragedii. Dlaczego, szczególnie w XX wieku świat stał się tak bardzo nieludzki? Bo ciągle ktoś chciał innym narzucić swoją wolę, zmusić kogoś do czegoś ${ }^{26}$. Wobec tego, coraz częściej da się słyszeć głos, że ludzie nie chcą być przedmiotem takiego działania, tak lub podobnie wyglądającej duszpasterskiej troski. Oni nie chcą być obiektem realizacji jakiegoś „wydumanego” pastoralnego projektu, który należy zrealizować pod szyldem, wymyślonego

${ }^{24}$ Por. tamże, s. 83-84. 97.

25 Por. U. R. Del Giudice, L'uno o l'altro? Il concetto di alterità tra differenza mistica e sintesi simbolica, Napoli 2009, s. 230.

26 Por. T. Špidlík, M. I. Rupnik, Una conoscenza integrale, dz. cyt., s. 199. 259. 
przy biurku lub też zupełnie na poczekaniu i przypadkowo, tego czy innego hasła. W imię idei, pomysłów, ludzie nie chcą być rzeczą.

Oni chcą się spotkać. Chcą spotkać osobę i poczuć się jak osoba. Chcą spotkać się z kimś, kto będzie w stanie oddać za nich życie, ponieważ będzie nosił w sobie inne, nowe życie, które przetrwa nawet śmierć. To dlatego w epoce, w której chrześcijanie żyli mentalnością sakramentalną, męczeństwo, oddanie własnego życia, było ostatecznie tryumfem życia, bo w śmierci objawione zostało światu nowe życie, życie mocniejsze niż śmierć. Chrześcijanie wiedzieli, że noszą w sobie nowe życie, dlatego mogli oddać własne ${ }^{27}$.

Jeśliby jednak ci sami chrześcijanie mieli na uwadze tylko projekty do realizacji, a nie otrzymane życie, stanęliby w opozycji do tego, do czego zostali powołani. Taką właśnie sytuację przedstawia historia pewnego młodego księdza: „Mówi się, że pierwsza parafia jest jak pierwsza miłość - zostaje w pamięci do końca życia. Coś w tym jest... Bez wątpienia, dane mi było zakochać się w jednej z nich... To był dobry czas. Byłem wolny. Rozpoczynałem podróż, której kresu nie znałem. Posługa sakramentalna, katecheza, konferencje, spotkania z grupami oraz te prywatne, po godzinach, w cztery oczy... Sporo nieprzewidywalnych zdarzeń, którymi usłana jest ścieżka każdego kapłańskiego życia. Po niedługim (wakacyjnym) czasie podejmowane działania wywoływały we mnie coraz więcej napięć i poczucia bezsensu. Inaczej to sobie wyobrażałem. Zastanawiało mnie, dlaczego spontaniczne głoszenie Boga nie jest czystą przyjemnością, lecz morderczym rzemiosłem. To zaś nieuchronnie prowadziło do nadmiernego stresu i zmęczenia. Nie wyrobię się, nie dam rady, nie spodoba się... Wiedziałem, że nie byłem pierwszy, który trzymał w swych zębach czerstwy chleb codzienności. Nie chciałem go wyrzucić. Po prostu chciałem, by mi smakował... Przecież to mój powszedni chleb! Początkowo nie rozumiałem, dlaczego tak jest... Owszem, wiedziałem, że wiele spraw nie zależy ode mnie. Mimo to byłem przekonany, że problem leży gdzieś indziej... Wziąłem pod lupę jeden z moich najbardziej zwariowanych dni, by przekonać się, gdzie... Największym ciężarem

${ }_{27}$ Por. M. Tenace, Dire l'uomo, t. 2. Dall'immagine di Dio alla somiglianza. La salvezza come divinizzazione, Roma 2014, s. 155-159. 
i bolączką mojej codzienności okazało się nieustanne zaczynanie od nowa! Modlitwa o poranku i w ciągu dnia nie miała wiele wspólnego z przeprowadzoną przeze mnie tego dnia katechezą. Podobnie było z głoszoną homilią i wieczorną konferencją. Rozmowy, nawet te duchowe, były także z innej bajki. Każdego dnia w mojej głowie znajdowało się kilkadziesiąt, tylko pozornie połączonych ze sobą wątków. Realnie nie było między nimi żadnej wspólnej płaszczyzny, choć wykonywałem je wszystkie pod sztandarem samego Boga. Każda czynność stanowiła oddzielną całość. Kreowałem nowe tematy, byleby zaspokoić apetyty mojego audytorium. Prawdziwą, chrześcijańską wiarę zastąpiłem ogromnym, intelektualnym wysiłkiem. Niemało mówiłem o Bogu, mało mówiłem z Nim! Byłem wykończony. Miałem dość... Dokonałem podziału (schizmy) na własnym sercu! Składało się ono z tysięcy mniejszych lub większych pragnień, działań, inicjatyw. Niestety, one wszystkie nie miały wyższego celu. Każde z nich było celem samym w sobie. W chwili realizacji znikały jak mydlana bańka. Ja zaś zaczynałem od początku... Nowe zadanie to nowy cel. Zamknięty krąg... Chciałem uciec z formalnego mówienia o Bogu. Pragnąłem Nim żyć. Moim marzeniem było takie przeżywanie porannej Jutrzni, by jej światło rzucało swój blask na każdy element dopiero co rozpoczętego dnia. Chciałem, by słuchacze mojej katechezy, homilii czy konferencji doświadczyli mojej modlitwy, mojego studium, mojego życia... - nie zaś tego, co z takim mozołem dla nich przygotowałem. Do tej pory zabiegałem o wiele, a potrzeba było mało albo tylko jednego (por. Łk 10, 42). Chodzi zatem o jedno źródło, o jeden cel, o jednego Boga, a w konsekwencji tego, o organiczne życie! Wtedy życie staje się o wiele prostsze"28.

Życie takiego człowieka, które jest sakramentalnym życiem na wzór Chrystusa i Maryi, jest podobne do warstw cebuli. Gdy odkryjemy jedną warstwę, natychmiast dochodzimy do kolejnej. Jedna rzecz znajduje swój sens w drugiej, druga w trzeciej, trzecia w czwartej... ${ }^{29}$.

28 A. Pastorczyк, Potrzeba jednego, https://profeto.pl/potrzeba-jednego- (odczyt Z dn. 24.10.2019 r.).

29 Por. N. Govekar (red.), Il rosso della piazza d’oro, dz. cyt., s. 123. 


\section{Księża Najświętszego Serca Jezusowego \\ - narodzeni w epoce krytycznej, żyjący zaś w epoce życia}

Bóg nigdy nie oszukuje człowieka. Jeśli obdarza go powołaniem do czegoś wielkiego, czym bez wątpienia jest życie sakramentalne w Zgromadzeniu Księży Najświętszego Serca Jezusowego, to tym samym wskazuje mu najlepszy (najprostszy) sposób jego realizacji. W Liście do Efezjan czytamy, że zostaliśmy „stworzeni w Chrystusie Jezusie do dobrych czynów, które Bóg z góry przygotował, abyśmy je pełnili” (Ef 2,10). Oznacza to, że one są do odkrycia, a nie do wymyślenia przez nas. W ludzkim życiu nie chodzi o wydawanie jakiegoś owocu, wymyślonego, wydumanego, wyśnionego, lecz chodzi o to, by wydawać owoc zgodnie z gatunkiem drzewa, którym się jest. Chodzi o owoce zgodne z przyjętym powołaniem. Konkretne drzewo powinno rodzić konkretny owoc. Owoce mango nie rosną na jabłoni, gruszki nie rosną na wierzbie, a śliwki na sośnie. To oznacza, że na świecie są tysiące owoców, których sercanie wcale przynosić nie muszą. Istotne jest to, aby przynosili owoc zgodnie ze swoim sercańskim charyzmatem.

W XXI wieku tysiące kobiet przeżywa swoje życiowe dramaty, gdyż nie są w stanie przyjąć wpisanego w nie powołania do bycia żoną i matką. Głodne sukcesu, spełnienia zawodowego, realizacji osobistych marzeń i planów, ciągłego projektowania, pozostają nieszczęśliwe i niespełnione. W swoim życiu mogą wydać wiele owoców. Pytanie jest jednak inne: czy wydają owoc zgodnie z gatunkiem drzewa, którym są?

Wobec powyższego, warto zastanowić się nad tym, jakie jest główne zadanie złego ducha? Do czego najbardziej kusi człowieka? Wydawałoby się, że do czynienia zła. To też, ale jest coś jeszcze. Zły duch tak kieruje ludźmi, aby nie realizowali swojego życiowego powołania. Chodzi mu o to, aby człowiek się z nim nie identyfikował, a w konsekwencji, aby nie objawiał tego światu. Na wszelkie sposoby będzie chciał zaoferować mu inny, lepszy produkt czy model. Ostatecznie zawsze będzie chodziło o substytut, bo oryginał każdy już uprzednio otrzymał. Zły duch będzie chciał oderwać sercanina od wydawania owocu zgodnego $\mathrm{z}$ charyzmatem Zgromadzenia i jego osobistym. Będzie wkładał mu do ręki inną regułę życia, nie tę, którą otrzymał w dniu pierwszej profesji zakonnej. 
Będzie mówił mu o innych zobowiązaniach, aniżeli te, które wypowiedział publicznie w dniu przyjmowanych święceń diakonatu i kapłaństwa. Jeśli sercanie nie będą żyli sercańskim charyzmatem, nawet jeżeli bezpośrednio nie będą czynili zła, ono samo, prędzej czy później, się pojawi. Złego ducha nie interesuje to, że będą robili coś niemoralnego, lecz że nie będą robili tego, do czego zostali powołani i co stanowi o ich sercańskiej tożsamości.

Jeżeli w klasztorach żyje się maryjnie, tzn. sakramentalnie, żyje się jako jeden w drugim, nie jeden naprzeciw drugiego lub co gorsza, jeden przeciw drugiemu, to wtedy życie zakonne jest prawdziwie chrześcijańskim życiem. W przeciwnym razie, gdy w klasztorze nie żyje się przyjętym Duchem Świętym, lecz praktykuje się własną filozofię życia, opartą o własną, wymyśloną przez siebie regułę życia, znowu, nie tę otrzymaną $\mathrm{w}$ dniu profesji zakonnej, taki klasztor staje się karykaturą.

Jeśli w życiu zakonnym jest coś, co może pociągać młodych i starszych, to z pewnością nie są to napięte mięśnie, nie jest to brawura ani też kolorowe maski, lecz braterstwo. Albo życie zakonne będzie odbiciem projektów i idei, albo będzie zdolne pokazać światu to, co Chrystus dokonuje w życiu tych, którzy przyjęli Jego łaskę powołania ${ }^{30}$. Osoby zakonne mogą pokazać to, tylko będąc razem, tworząc grupę przyjaciół, którzy w trudach codzienności umieją, tak jak we chrzcie, wzajemnie dla siebie umierać i zmartwychwstawać3 ${ }^{31}$. Nowa epoka nie chce strategii, form, metod..., lecz życia wspólnego.

Idee są nudne, szkolne, sztampowe, zaś opowiadanie o życiu w Chrystusie, przeciwnie, jest pociągające, bo przeżyte. Wystarczy, że sercanin opowie komuś krótką historię swojego powołania. Czyż nie będzie słuchał z zachwytem? Będzie, ponieważ idei i projektów są tysiące, a ludzi żyjących sakramentalnie, słyszących głos Boga, spotykających Go codziennie na Eucharystii i we wspólnocie, noszących Go pod sercem jak Maryja, jest tak niewielu.

Chodzi o doświadczenie niewymyślone, niewymarzone, niewyśnione, lecz przeżyte: „To wam oznajmiamy, co było od początku, cośmy usłyszeli

\footnotetext{
${ }^{30}$ Por. tamże, s. 58-59.

31 Por. tamże, s. 42.
} 
o Słowie życia, co ujrzeliśmy własnymi oczami, na co patrzyliśmy i czego dotykały nasze ręce" $(1 \mathrm{~J} 1,1)$. Słowo Boże jest widzeniem, jest dotykaniem. Biblia jest Słowem Bożym dlatego, że jest w niej Chrystus, a Chrystus jest wcielonym Słowem. To nie jest rzecz marginalna, gdyż widzenie i dotykanie stoją w centrum ludzkiego aktu chrześcijańskiej wiary.

\section{Zakończenie}

Współczesny człowiek jest dzieckiem epoki, w której żyje. Ta z kolei została naznaczona kulturowym bagażem epoki ją poprzedzającej. Kto w trwającej obecnie organicznej epoce życia chce doświadczyć jego nowości, musi zostawić ten kulturowy bagaż. Apostoł Narodów podpowiada: „Wyrzućcie więc stary kwas, abyście stali się nowym ciastem, bo przecież przaśni jesteście" (1 Kor 5,7).

Ikona Maryi w tajemnicy Błogosławionego Macierzyństwa wyraża chrześcijański styl życia w Duchu Świętym, który jest życiem sakramentalnym, dynamicznym, życiem odkrywcy, życiem objawiającym światu otrzymaną i przyjętą nowość. Tego maryjnego stylu życia chrześcijanie ani nie pożyczyli, ani nie skopiowali od nikogo. To jest coś na wskroś oryginalnego, coś, czego świat im nie może dać, ale za to oni mogą dać to światu.

\section{Bibliografia}

Bonaccorso G., Il rito e l'altro. La liturgia come tempo, linguaggio e azione, Città del Vaticano 2001.

Bonaccorso G., La comunicazione non verbale in un'ecclesiologia dell'incontro, „Annali Studi Religiosi” 1(2000), s. 55-68.

Del Giudice U. R., Luno o l'altro? Il concetto di alterità tra differenza mistica e sintesi simbolica, Napoli 2009.

Govekar N. (red.), Il rosso della piazza d'oro. Intervista a Marko Ivan Rupnik su arte, fede ed evangelizzazione, Roma 2013.

Guardini R., La fine dellepoca moderna, Brescia $1960^{2}$. 
Guardini R., La funzione della sensibilità nella coscienza religiosa, w: G. Sommavilla (red.), Scritti filosofici, t. 2, Milano 1964, s. 137-190.

Pastorczyk A., Potrzeba jednego, https://profeto.pl/potrzeba-jednego- (odczyt $\mathrm{z}$ dn. 24.10.2019 r.).

Pellegrino C., Maria di Nazaret, Profezia del Regno. Un approccio narrativo a Lc 1,34, Roma 2014.

Salmann E., L'evento intercorporeo tra verità e rito, w: A. N. Terrin (red.), Liturgia e incarnazione, Padova 1997, s. 21-44.

Špidlík T., La preghiera secondo la tradizione dell'Oriente cristiano, Roma 2008.

Špidlík T., Rupnik M. I., Una conoscenza integrale. La via del simbolo, Roma 2010.

Tenace M., Cristiani si diventa. Dogma e vita nei primi tre concili, Roma 2013.

Tenace M., Dire l'uomo, t. 2. Dall'immagine di Dio alla somiglianza. La salvezza come divinizzazione, Roma 2014.

Wons K., Cała piękna. Lectio divina z Maryją, Kraków 2017.

Ks. mgr lic. Adam Pastorczyk - sercanin, absolwent Wyższego Seminarium Misyjnego Księży Sercanów w Stadnikach i Uniwersytetu Gregoriańskiego w Rzymie; doktorant Instytutu Teologii Fundamentalnej, Ekumenii i Dialogu Uniwersytetu Papieskiego Jana Pawła II w Krakowie. 